DOI: https://doi.org/10.31933/dijms.v3i1

Received: 16 July 2021, Revised: 25 August 2021, Publish: 9 October 2021

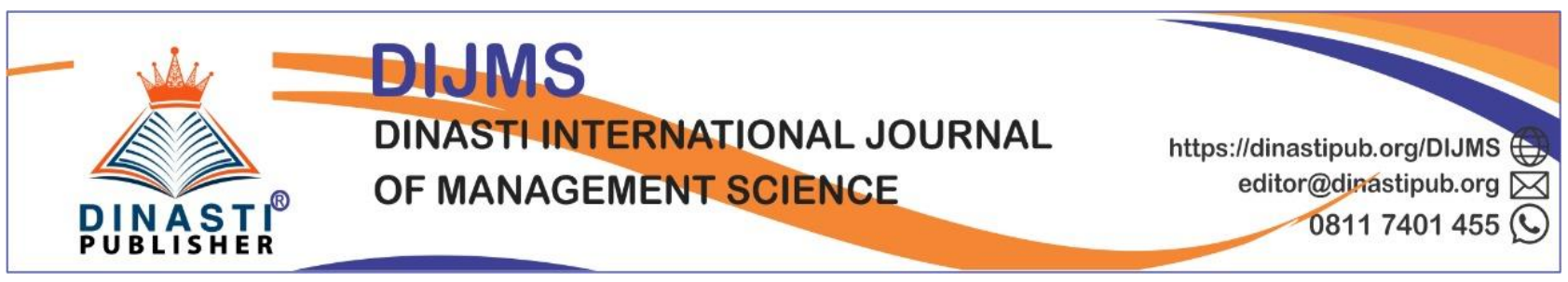

\title{
THE INFLUENCE OF SERVICE QUALITY AND PRODUCT QUALITY ON CUSTOMER SATISFACTION THAT IMPLICATIONS ON REPURCHASE INTEREST
}

\author{
Agung Hudaya ${ }^{1}$, Djumarno Djumarno ${ }^{2}$, Siti Djubaedah ${ }^{3}$ \\ 1) Mercu Buana University, Jakarta, Indonesia, agung24@mercubuana.ac.id \\ 2) Mercu Buana University, Jakarta, Indonesia, djumarno@mercubuana.ac.id \\ ${ }^{3)}$ UPN, Jakarta, Indonesia, jubaedah@upnvj.ac.id
}

\section{Corresponding Author: First Author}

\begin{abstract}
The food industry is quite promising for businesses both large and small businesses, quality of service is an aspect that is often used by the business field of food and beverage, related to quality of service, must often associated more with the quality of products, it is thus an aspect that should considered by the company to get customer satisfaction and repurchase interest. This research will be more in-depth about mobile restaurants, or food trucks, because they are much in demand by novice entrepreneurs and are in great demand by fast food customers. This research is a quantitative study conducted to examine the effect of service quality and product quality from food trucks that affect customer satisfaction and repurchase interest by food truck customers. It took 120 respondents in the study who were randomly selected to answer the questionnaire.
\end{abstract}

Keywords: service quality, product quality, customer satisfaction, repurchase intention.

\section{INTRODUCTION}

The culinary business in Indonesia is quite diverse, ranging from traditional to modern, such as fast food, this is a positive thing because the economy in Indonesia is quite good, with good people's purchasing power, the food industry in Indonesia is a potential market for entrepreneurs. There are many modifications to the type of food that combines taste and presentation method, but it is still rare to innovate with a seller's style, such as selling on a car, or a food truck.

Service quality is one of the factors that affect customer satisfaction. (Garcia et al., 2020), then the next thing is to prioritize the quality of the product from the business itself because indeed, product quality is a supporting thing where the company can run sustainably, by improving the quality of the product, customer satisfaction will be obtained by the restaurant. themselves (Ikhsani $\&$ Ali, 2017). This was also stated by previous research which explained that service quality and product quality were the key to how a company can get customer satisfaction (M \& Ali, 
2017). Which explains if the quality of service is improved and product quality is improved, customer satisfaction will increase simultaneously.

Contiunity company will be acquired by line of business if found to be interest in buying back repeatedly, interest buy-back is a situation where customers menyembatkan money and time to buy a product or service repeatedly (Slack et al., 2020). A business will get repurchase interest if a business prioritizes the quality of service in their business, because with good service quality, repurchase interest will increase simultaneously (Kasiri et al., 2017) .

Repurchase interest is something that is planned by the company, the high and low interest in repurchasing a product or service, it will be based on the quality of the product or service served by the restaurant, this is according to research from (Gök et al., 2019 ), which states that if the quality of the product will affect customer satisfaction and repurchase intention of the product. (Chinomona \& Maziriri, 2017).

\section{LITERATURE REVIEW}

Service quality is defined as varied, such as being suitable for use by customers so that service quality meets customer desires, (Kotler \& Keller, 2016), service quality as a feature of the characteristics of a product offered with its ability to meet the wishes of customers, implied or implied desires. In this case, the quality of service is truly customer-centered. With this definition, if the company has good quality, then customer needs will be exceeded. Companies usually meet the needs of almost all of their customers, both potential customers and not.

In the journal (Ikhsani \& Ali, 2017) Product quality is an important thing that must be considered, with that product quality, the factors behind product quality include performance, reliability, conformance specifications, and durability, some of these things must be considered because with Combining these things can form a good product quality strategy

In accordance with the journal (Wantara \& Tambrin, 2019) product quality is something that is considered by companies to get customer satisfaction, so it becomes a consideration for companies how companies have concepts to make good product quality.

Customer satisfaction is an important factor supporting the success of a company, therefore, companies must be able to know and study the factors that can satisfy customers in order to measure customer satisfaction. According to (Kotler, 2012) in (Tjiptono \& Fandy, 2015) there are several methods that companies can use to measure and monitor the satisfaction of their customers and competitors' customers,

Customer satisfaction is a situation where customer desires are achieved or exceeded, such a situation will be based on other factors behind it. Customer satisfaction is the company's achievement as a result of the combination of several strategies to get customer satisfaction (Huang et al., 2019)

Repurchase is a step that occurs after a purchase is made. Repurchase is where consumers are satisfied with a product that matches expectations with the expected performance, will create a satisfaction that encourages the creation of repeat purchases of the same product or brand in the future and will tell good things about the brand (Kotler, 2012). ) 
When consumers have felt the value of a product or company through positive experiences that have been obtained previously, they will feel happy and satisfied. This will make consumers intend to repurchase because of the emotional bond of the experience they have gained.

\section{RESEARCH METHODS}

The reason for using SEM analysis techniques in management research is that it can confirm the dimensions of a concept or factor (which is often used in management) and its ability to measure the theoretical effects of variables. The advantage of the application of SEM in management research is due to its ability to present a comprehensive model along with its ability to confirm the dimensions of a concept or factor (which is commonly used in management) and its ability to measure the influence of theoretical relationships. Usually SEM is seen as a combination of factor analysis and regression analysis, and of course it is applied separately only in confirmatory factor analysis or only in regression analysis.

The population is a generalization area consisting of: objects/subjects that have certain qualities and characteristics determined by researchers to study and then draw conclusions (Sugiyono, $2011,61)$. The population in this study were people who had visited the restaurant.

To get the number of samples that match the criteria, the researchers took research samples from April 2019 to May 2019. The researcher with his judgment determines the sample population from the unknown number of visitors.

Thus the number of samples that will be used for this research is 120 consumers or customers who eat meals come to restaurants.

The sample is part of the number and characteristics possessed by the population. (Leguina, 2015) states that the sample size that should be met in the SEM analysis technique is a minimum of 100 and a maximum of 200. (Sugiyono, 2014) suggests that the best sample size for multivariate sizes is 5 to 10. This study uses 13 indicators so that using estimation based on the number of parameters obtained a sample size of 100-200 respondents.

\section{FINDINGS AND DISCUSSION}

\section{Evaluation of Measurement (Outer) Model}

Convergent validity, discriminant validity and reliability of composite. This is something that must be considered in research using SEM with SmartPLS.

Convergent validity, the correlation between reflexive indicator scores and latent variable scores. This study uses a loading of 0,5 up to 0.6 is considered adequate,

Discriminant validity, measuring reflexive indicators based on cross loading with latent variables. Another method is to compare the value of the square root of average variance extracted (AVE) of each construct with the correlations between other constructs in the model.

Composite reliability, construct declared reliable if the value of composite reliability above 0,70 and Cronbach's alpha above 0.60 though not an absolute standard.

\section{Convergen Validity}

Table 1. Convergent Validity Test Results

\begin{tabular}{cccc}
\hline Variable & Indicator & Outer Loading & Information \\
\hline Service & $\mathrm{X} 1.1$ & 0.856 & Valid \\
quality & $\mathrm{X} 1.2$ & 0.738 & Valid
\end{tabular}




\begin{tabular}{cccc}
\hline & X1.3 & 0.762 & Valid \\
& X1.4 & 0.774 & Valid \\
& X1.5 & 0.769 & Valid \\
\hline Product & X2.1 & 0.835 & Valid \\
quality & X2.2 & 0.772 & Valid \\
& X2.3 & 0.847 & Valid \\
& X2.4 & 0.857 & Valid \\
\hline Customer & Z1.1 & 0.863 & Valid \\
satisfaction & Z1.2 & 0.849 & Valid \\
& Z1.3 & 0.847 & Valid \\
& Z1.4 & 0.841 & Valid \\
& Z1.5 & 0.805 & Valid \\
\hline Repurchase & Y1.1 & 0.872 & Valid \\
interest & Y1.2 & 0.819 & Valid \\
& Y1.3 & 0.908 & Valid \\
& Y1.4 & 0.908 & Valid \\
\hline
\end{tabular}

Source: Processed data

The convergent validity of the measurement model using reflective indicators is assessed based on the outer loading factor indicator that measures the construct.

Table 2. AVE

\begin{tabular}{lc}
\hline \multicolumn{1}{c}{ VARIABEL } & $\begin{array}{c}\text { Average Variance } \\
\text { Extracted (AVE) }\end{array}$ \\
\hline Service quality & 0.610 \\
Product quality & 0.686 \\
Customer satisfaction & 0.707 \\
Repurchase interest & 0.770 \\
\hline
\end{tabular}

Sumber : Processed data

The validity test was also carried out by using a test method comparing the square root value of average variance extracted $(A V E)$ in each construct with the correlations between other constructs contained in the model .

\section{Composite Reliability dan Cronbach's Alpha}

Table 3. Composite Reliability dan Cronbach's Alpha

\begin{tabular}{lcc}
\hline Variabel & Cronbach's Alpha & $\begin{array}{c}\text { Composite } \\
\text { Reliability }\end{array}$ \\
\hline Service quality & 0.844 & 0.886 \\
Product quality & 0.852 & 0.897 \\
Customer satisfaction & 0.897 & 0.924
\end{tabular}




$\begin{array}{lll}\text { Repurchase interest } & 0.900 & 0.931\end{array}$

Sumber : Processed data

With reference to the results of smartPLS output above shows all of the output has a value greater than 0,70 to Cronbach's alpha and composite reliability 0.60 . With this it is stated that each form of research forms results that are supported by good reliability.

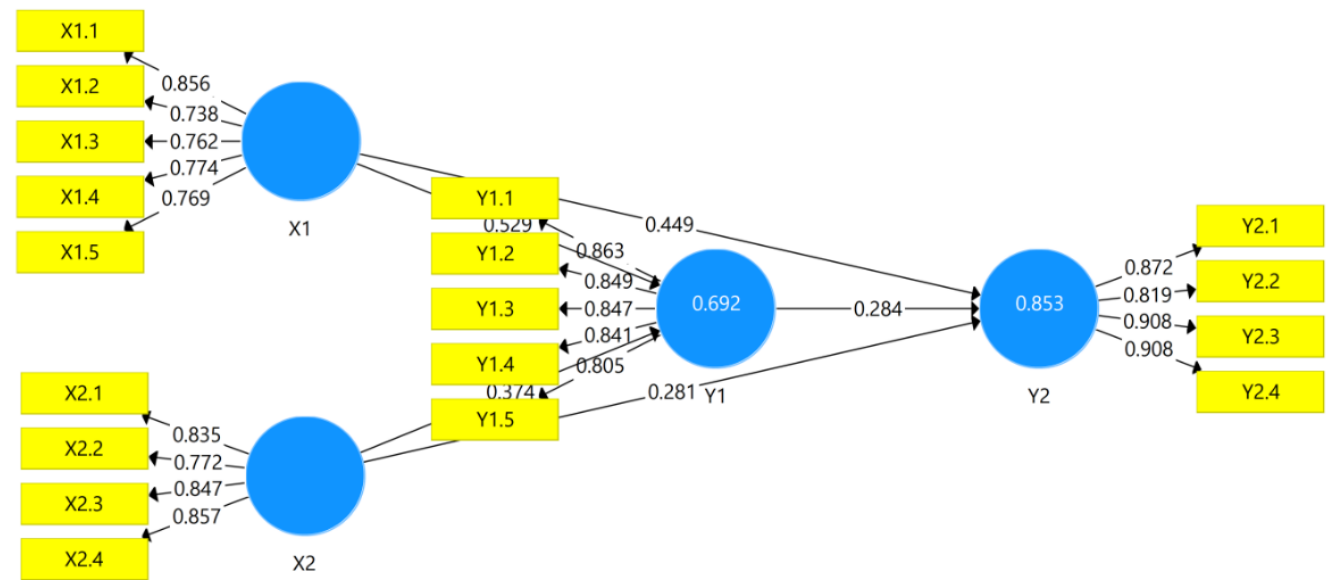

Figure 1. PLS Algorithm Results Display Image

\section{Structural Test}

Structural Model Testing (Inner Model)

Calculation of Effect between Variables

Table 4. Path Coefficients (Mean, STDEV, t-Value)

\begin{tabular}{|c|c|c|c|c|}
\hline Variabel & $\begin{array}{l}\text { Original } \\
\text { Sample } \\
(\mathrm{O})\end{array}$ & $\begin{array}{c}T \\
\text { Statistics }\end{array}$ & $P$ Values & $\begin{array}{l}\text { Significance } \\
\text { Level }\end{array}$ \\
\hline $\begin{array}{l}\text { Service quality -> customer } \\
\text { satisfaction }\end{array}$ & 0.529 & 5.416 & 0.000 & $<0.05$ \\
\hline $\begin{array}{l}\text { Product quality -> customer } \\
\text { satisfaction }\end{array}$ & 0.974 & 3.912 & 0.006 & $<0.05$ \\
\hline $\begin{array}{l}\text { Quality of service -> interest in } \\
\text { repurchasing }\end{array}$ & 0.449 & 6.006 & 0.003 & $<0.05$ \\
\hline $\begin{array}{l}\text { Product quality -> repeat } \\
\text { purchase interest }\end{array}$ & 0.281 & 2.772 & 0.006 & $<0.05$ \\
\hline $\begin{array}{l}\text { Customer satisfaction }->\text { repeat } \\
\text { purchase interest }\end{array}$ & 0.284 & 3.128 & 0.002 & $<0.05$ \\
\hline
\end{tabular}

Sumber : Processed data

Based on the table above, it can be seen that the measurement model formed is the Equation Model as below: 
$\mathrm{Y} 1=0.529 \mathrm{X} 1+0.374 \mathrm{X} 2$

$\mathrm{Y} 2=0.449 \mathrm{X} 1+0.281 \mathrm{X} 2+0.284 \mathrm{Y} 2$

Where,

$\mathrm{X} 1=$ service quality

$\mathrm{X} 2$ = product quality

$\mathrm{Y} 1=$ customer satisfaction

$\mathrm{Y} 2=$ repurchase interest

\section{Hypothesis test}

The table above provides proof of the research hypothesis on the effect given on product quality and price. Customer satisfaction affects customer loyalty

a) The first hypothesis which states that service quality affects customer satisfaction can be proven true. This can be seen from the t-statistical value of 5,416 which is greater than the value of $t$ table $=1.96$, and the probability value of 0.000 which is smaller than the specified critical value limit of 0.05. Thus it is stated that service quality has a significant and significant effect on customer satisfaction .

there is an influence generated through the service quality variable on customer satisfaction, service quality has a role in the increase or decrease in customer satisfaction, this becomes a benchmark that is generated if the dominant service quality has an increase then customer satisfaction also tends to increase, this is because the results of research is positive, in this case customer satisfaction is influenced by service quality. This is in accordance with research conducted by, (Shamsudin et al., 2019), (M \& Ali, 2017), (Huang et al., 2019),

b) The second hypothesis which states that product quality affects customer satisfaction can be proven true. This can be seen from the t-statistical value of 3.912 which is greater than the ttable value $=1.96$, and the probability value of 0.000 which is smaller than the specified critical value limit of 0.05 . Thus it is stated that product quality has a significant effect on customer satisfaction.

The results of the study show that there is an influence resulting from price on customer satisfaction, price as a variable chosen by researchers shows the existence of properties that can affect customer satisfaction, prices which include the application of perceptions of a study of consumers before they buy will have an impact on customer satisfaction, because satisfaction will increase in the minds of consumers, if the price offered really fits the perceptions that exist in consumers, this is in accordance with research conducted by (Nguyen et al., 2019), (Rama, 2020), (Suhaily \& Soelasih, 2017 ), (Surjaatmadja \& Purnawan, 2018) .

c) The third hypothesis which states that service quality has an effect on repurchase interest can be proven true. This can be seen from the statistical t value of 6,006 which is smaller than the value of $t$ table $=1.96$, and the probability value of 0.000 which is smaller than the specified critical value limit of 0.05 . Thus it is stated that service quality has a significant and significant effect on repurchase intention.

good product quality will have an impact on customer loyalty, because if the product quality is good, the quality is in accordance with customer expectations, the better product quality will have an impact on customer loyalty, customer loyalty is very important for a business, because with customer loyalty, the company will be able to run sustainably, this is in accordance with 
research conducted by, (M \& Ali, 2017), (Hudaya, 2018), (Hoe \& Mansori, 2018), (Waluya et al., 2019) .

d) The fourth hypothesis which states that product quality has an effect on repurchase interest is proven to be true. This can be seen from the t-statistical value of 2.772 which is greater than the t-table value $=1.96$, and the probability value of 0.006 which is smaller than the specified critical value limit of 0.05 . Thus it is stated that product quality has a significant effect on repurchase intention.

Prices that have an influence on customer loyalty. The results of the study show that there is an influence produced by price on customer loyalty, price is a focus for some companies because price is indeed one of the factors to get customer loyalty, this will be sustainable because a good price will have an impact on customer loyalty. The results of the research are in accordance with those conducted by, (Sunaryo, 2019), (Shamsudin et al., 2019), (Hudaya, 2020), (Slack et al., 2020).

e) The fifth hypothesis which states that customer satisfaction has an effect on repurchase interest can be proven true. This can be seen from the t-statistical value of 3.128 which is greater than the t-table value $=1.96$, and the probability value of 0.002 which is smaller than the specified critical value limit of 0.05 . Thus it is stated that customer satisfaction has a significant and significant effect on repurchase interest.

The results of the study indicate that there is an influence resulting from customer satisfaction on customer loyalty. This shows that customer satisfaction will make customers come back and buy products again, with this customer satisfaction must be properly maintained, with high customer satisfaction customers will not hesitate to buy products again and talk about good things to others. (Djumarno et al., 2018), (M \& Ali, 2017), (Wibowo, 2015)

\section{CONCLUSION}

1. Quality of service affects customer satisfaction. In this study, it is proven that service quality is one of the important roles to get customer satisfaction for food truck snacks. Food truck snacks are becoming a trend, especially for teenagers, therefore the quality of service in the form of direct services and online services plays a role in getting customer satisfaction. Many people who order products directly, must be served well, and services in the form of places to eat to eat in and food to take home are considerations that must be considered. Online ordering is also a second focus for the restaurant because pakagin has become a matter of concern lately, all services carried out must be optimal, because with optimal service, customer satisfaction will increase in tandem.

2. The quality of food truck snacks must be considered because it is proven that good product quality will get more and more customer satisfaction. Customers tend to be satisfied, with the food paid, satisfied customers are customers who feel the product exceeds previous expectations, customers who are satisfied with the product will buy the product repeatedly, customers who feel satisfied with the product will have a positive perception of other products., therefore product quality will be improved to get increased customer satisfaction.

3. The quality of service will be improved to get maximum customer loyalty, customer loyalty is a goal for the company because with loyal customers, the company will be able to run sustainably, a company that runs sustainably, is a company that has a long life in business, service quality will has a long impact on foodtruck hawker customers, because with that, good customers are customers who have a positive mind for the company or restaurant with the products they have 
purchased, customers who are loyal to service will buy the same product from one company. Because this research is proven by improving service, customer loyalty will increase.

4. Good product quality will give a feeling of loyalty to the company from customers who have bought their products. Because with the quality of the product, whether or not it will have an impact on loyal customers or not, it would be better if the products from food truck hawker restaurants were paid more attention to get loyal customers, this would create feelings for customers, with that. Good product quality will have an impact on loyal customers.

5. A reflection of loyal customers are customers who feel satisfied with the company both in terms of service quality or product quality, customer satisfaction becomes a bridge for companies to get customer loyalty, companies often compete to get satisfaction for customers, because with customers who Satisfied will get high loyalty, and loyal customers will have a positive effect on the company. Because with loyal customers the company can continue to grow and be sustainable.

\section{RECOMMENDATION}

1. The quality of service becomes a focus for the restaurant because the quality of service that is considered will have an impact on the progress or decline of the company or restaurant, with this the quality of restaurant service is good, but must be maintained either in person or online, the ease of ordering will be a strong focus the restaurant should pay attention.

2. The quality of food truck snacks is good, with this the researcher urges to maintain product quality, and develop product quality to be even better, both in terms of flavor variants and product development, because with good product quality, customer satisfaction and loyalty will be obtained by company

3. Customer satisfaction will be created automatically if the aspects behind it are considered, for example, service quality and product quality, these two aspects become a benchmark for customers to be satisfied or not by the restaurant from the point of view of service quality and product quality point of view, high customer satisfaction. good will have an impact on loyalty afterwards, therefore customer satisfaction must be maintained properly.

4. Customer loyalty will be the picture received by consumers of the products or services they have purchased, customer loyalty in this case is influenced by customer satisfaction, service quality and product quality, therefore the loyalty that has been obtained will have an impact on the progress or decline of a business. . Because loyalty is an achievement obtained by the company through its customers, through trust in the restaurant. Loyalty is a situation where customers can buy products continuously.

\section{BIBLIOGRAPHY}

Chen, L., Li, Y. Q., \& Liu, C. H. (2019). How airline service quality determines the quantity of repurchase intention - Mediate and moderate effects of brand quality and perceived value. Journal of Air Transport Management. https://doi.org/10.1016/j.jairtraman.2018.11.002

Chinomona, R., \& Maziriri, E. T. (2017). The influence of brand awareness, brand association and product quality on brand loyalty and repurchase intention: A case of male consumers for cosmetic brands in South Africa. Journal of Business and Retail Management Research. https://doi.org/10.24052/jbrmr/v12is01/tiobabaapqoblariacomcfcbisa

Djumarno, Anjani, S., \& Djamaluddin, S. (2018). Effect of Product Quality and Price on Customer Loyalty through Customer Satisfaction. International Journal of Business and Management 
Invention (IJBMI).

Garcia, J. M., De Lamonica Freire, O. B., Almeida Santos, E. B., \& Andrade, J. (2020). Fatores que afetam a satisfacao e a lealdade aos sites de compras coletivas factors affecting satisfaction and loyalty to online group buying. REGE-REVISTA DE GESTAO.

Ghezelbash, S., \& Khodadadi, H. (2017). Evaluating the Impact of Promotion Price, Product Quality, Service Quality, Customer Satisfaction and Repeating Purchase Incentives (Case Study: Amiran Chain Stores). Journal of Internet Banking and Commerce.

Gök, O., Ersoy, P., \& Börühan, G. (2019). The effect of user manual quality on customer satisfaction: the mediating effect of perceived product quality. Journal of Product and Brand Management. https://doi.org/10.1108/JPBM-10-2018-2054

Hoe, L. C., \& Mansori, S. (2018). The Effects of Product Quality on Customer Satisfaction and Loyalty: Evidence from Malaysian Engineering Industry. International Journal of Industrial Marketing. https://doi.org/10.5296/ijim.v3i1.13959

Huang, P. L., Lee, B. C. Y., \& Chen, C. C. (2019). The influence of service quality on customer satisfaction and loyalty in B2B technology service industry. Total Quality Management and Business Excellence. https://doi.org/10.1080/14783363.2017.1372184

Hudaya, A. (2018). Analisis Faktor yang mempengaruhi keputusan pembelian (studi kasus kedai gerobak kopi Seruput - Jakarta).

Hudaya, A. (2020). Analysis of Customer Loyalty Through Customer Satisfaction in Kedai Coffee (Case Study of SMEs in Jakarta Indonesia). Dinasti International Journal of Management Science. https://doi.org/10.31933/dijms.v1i6.407

Ikhsani, K., \& Ali, D. H. (2017). Keputusan Pembelian: Analisis Kualitas Produk, Harga dan Brand Awareness (Studi Kasus Produk Teh Botol Sosro di Giant Mall Permata Tangerang). In Jurnal SWOT.

Ilyas, G. B., Rahmi, S., Tamsah, H., Munir, A. R., \& Putra, A. H. P. K. (2020). Reflective model of brand awareness on repurchase intention and customer satisfaction. Journal of Asian Finance, Economics and Business. https://doi.org/10.13106/JAFEB.2020.VOL7.NO9.427

Javed, M. K., \& Wu, M. (2020). Effects of online retailer after delivery services on repurchase intention: An empirical analysis of customers' past experience and future confidence with the retailer. Journal of Retailing and Consumer Services. https://doi.org/10.1016/j.jretconser.2019.101942

Kasiri, L. A., Guan Cheng, K. T., Sambasivan, M., \& Sidin, S. M. (2017). Integration of standardization and customization: Impact on service quality, customer satisfaction, and loyalty. Journal of Retailing and Consumer Services. https://doi.org/10.1016/j.jretconser.2016.11.007

Kotler, P. (2012). Marketing management/Philip Kotler, Kevin Lane Keller. Pearson Education International.

Kotler, P., \& Keller, K. L. (2016). Marketing Mangement. In Pearson Edition Limited.

Leguina, A. (2015). A primer on partial least squares structural equation modeling (PLS-SEM). International Journal of Research \& Method in Education. https://doi.org/10.1080/1743727x.2015.1005806

Leonnard. (2018). PERCEIVED SERVICE QUALITY , PERCEIVED VALUE FOR MONEY, SATISFACTION AND REPURCHASE INTENTION : AN EVALUATION ON PRIVATE UNIVERSITY SERVICES. International Journal of Commerce and Finance.

M, A., \& Ali, H. (2017). Model Kepuasan Pelanggan: Analisis Kualitas Produk Dan Kualitas Layanan Terhadap Citra Merek Pada GIANT Citra Raya Jakarta. Jurnal Manajemen. 
https://doi.org/10.24912/jm.v21i3.254

Nguyen, P. T., Ali, H., \& Hudaya, A. (2019). Model Buying Decision And Repeat Purchase: Product Quality Analysis. Dinasti International Journal of Management Science.

Normasari, S. (2013). PENGARUH KUALITAS PELAYANAN TERHADAP KEPUASAN PELANGGAN, CITRA PERUSAHAAN DAN LOYALITAS PELANGGAN Survei padaTamu Pelanggan yang Menginap di Hotel Pelangi Malang. Jurnal Administrasi Bisnis S1 Universitas Brawijaya.

Rahman, H. A., \& Sitio, A. (2020). THE EFFECT OF PROMOTION AND PRODUCT QUALITY THROUGH PURCHASE DECISION ON THE CUSTOMER SATISFACTION OF BOHEMIAN PROJECT.ID PRODUCTS. International Journal of Engineering Technologies and Management Research. https://doi.org/10.29121/ijetmr.v6.i1.2019.346

Rama, A. (2020). Strategic pricing by Islamic banks and the impact on customer satisfaction and behavioral intention. Journal of Islamic Accounting and Business Research. https://doi.org/10.1108/JIABR-04-2019-0078

Saleem, M. A., Zahra, S., \& Yaseen, A. (2017). Impact of service quality and trust on repurchase intentions - the case of Pakistan airline industry. Asia Pacific Journal of Marketing and Logistics. https://doi.org/10.1108/APJML-10-2016-0192

Sari, D. A. T. (2020). Role of consumer satisfaction in mediating effect of product quality on repurchase intention. International Research Journal of Management, IT and Social Sciences. https://doi.org/10.21744/irjmis.v7n1.839

Setyowati, E., \& Purwogati, E. (2017). THE INFLUENCE OF PRODUCT QUALITY, FACILITY AND SERVICE QUALITY TOWARDS CUSTOMER SATISFACTION: CASE STUDY ON CUSTOMER SATISFACTION OF WARUNG APUNG MARITIM FOOD STALL, WEST SURABAYA. Russian Journal of Agricultural and Socio-Economic Sciences. https://doi.org/10.18551/rjoas.2017-04.20

Shamsudin, M. F., Esa, S. A., \& Ali, A. M. (2019). Determinants of customer loyalty towards the hotel industry in Malaysia. International Journal of Innovation, Creativity and Change.

Slack, N., Singh, G., \& Sharma, S. (2020). The effect of supermarket service quality dimensions and customer satisfaction on customer loyalty and disloyalty dimensions. International Journal of Quality and Service Sciences. https://doi.org/10.1108/IJQSS-10-2019-0114

Sugiyono. (2014). Metode Penelitian Pendidikan pendekatan Kuantitatif, Kualitatif dan R\&D. In METODE PENELITIAN ILMIAH.

Suhaily, L., \& Soelasih, Y. (2017). What Effects Repurchase Intention of Online Shopping. International Business Research. https://doi.org/10.5539/ibr.v10n12p113

Sullivan, Y. W., \& Kim, D. J. (2018). Assessing the effects of consumers' product evaluations and trust on repurchase intention in e-commerce environments. International Journal of Information Management. https://doi.org/10.1016/j.ijinfomgt.2017.12.008

Sunaryo, I. (2019). EFFECTS OF FOOD QUALITY, SERVICE QUALITY, PRICE, ENVIRONMENT, AND LOCATION TOWARDS CUSTOMER LOYALTY OF INDONESIA'S LOCAL FAST FOOD INDUSTRY. J@ti Undip : Jurnal Teknik Industri, 14(3). https://doi.org/10.14710/jati.14.3.119-128

Surjaatmadja, S., \& Purnawan, D. (2018). International Review of Management and Marketing Store Image, Service Quality, and Familiarity on Purchase Intention of Private Label Brand in Indonesia. International Review of Management and Marketing, 8(1).

Tandon, A., Aakash, A., \& Aggarwal, A. G. (2020). Impact of EWOM, website quality, and product satisfaction on customer satisfaction and repurchase intention: moderating role of 
shipping and handling. International Journal of Systems Assurance Engineering and Management. https://doi.org/10.1007/s13198-020-00954-3

Tjiptono, F. (2014). Pemasaran Jasa - Prinsip, Penerapan, dan Penelitiab. In 1.

Tjiptono, F. (2019). Strategi Pemasaran Edisi 3. Yogyakarta: Andi.

Tjiptono, \& Fandy. (2015). Strategi Pemasaran. In Yogyakarta: Andi.

Waluya, A. I., Iqbal, M. A., \& Indradewa, R. (2019). How product quality, brand image, and customer satisfaction affect the purchase decisions of Indonesian automotive customers. International Journal of Services, Economics and Management. https://doi.org/10.1504/IJSEM.2019.100944

Wantara, P., \& Tambrin, M. (2019). The Effect of Price and Product Quality Towards Customer Satisfaction and Customer Loyalty on Madura Batik. International Tourism and Hospitality Journal.

Wibowo, A. (2015). PENGARUH RELATIONSHIP MARKETING TERHADAP LOYALITAS PELANGGAN (Survei pada Pelanggan Savana Hotel dan Convention Malang). Jurnal Administrasi Bisnis S1 Universitas Brawijaya.

Xu, L., Blankson, C., \& Prybutok, V. (2017). Relative contributions of product quality and service quality in the automobile industry. Quality Management Journal. https://doi.org/10.1080/10686967.2017.11918498 